JOURNAL OF RECEPTOR RESEARCH, 13(1-4), 369-378 (1993)

\title{
A PARTIALLY AUTOMATED RADIOLIGAND BINDING ASSAY SYSTEM FOR USE IN CLINICAL AND PHARMACEUTICAL RESEARCH
}

\author{
B. Liebl ${ }^{1 *}$, T. Anhäupl ${ }^{2}$, E. Haen ${ }^{1}$, B. Günster ${ }^{3}$, M. Georgieff ${ }^{2}$ \\ 1) Walther-Straub-Institut für Pharmakologie und Toxikologie, Universität München; \\ 2) Universitătsklinik für Anästhesiologie, Universität UIm; \\ 3) Zinsser Analytic, Tecan Robotics, Frankfurt/M.; Germany
}

\begin{abstract}
Using a Tecan robotic sample processor and IBM compatible PCs we have developed a flexible, partially automated radioligand binding assay system. It handles pipetting parameters of up to 16 saturation or competition experiments at a time with up to 24 radioligand- or competitor-concentrations in a range over 4 orders of magnitude per experiment. The system provides enough flexibility so that all pipetting parameters including different tube-, rack-sizes, sample volumina and pipetting sequences may be easily adapted to the large variety of experimental requirements in binding assays. It rationalizes and increases assay throughput (up to $70 \%$ spare of working time), improves reliance and reproducibility of results. Radioactive exposure is minimized to the time preparing the radioligand working solution and transferring the sample tubes to and from the sample processor. The system has proven effective in various investigations on binding interactions, as well as in clinical studies on receptor expression under physiologic, pathological and therapeutic conditions.
\end{abstract}

\section{INTRODUCTION}

Binding assays with radiolabeled drugs are used to measure and characterize the interactions of ligands with a variety of receptors for hormones, neurotransmitters and drugs. Over the past two decades radio- 
ligand binding techniques have become increasingly important in clinical research and in the pharmaceutical industry as an essential part in drug discovery and evaluation. In clinical investigations receptor expression is studied in tissue samples from healthy, sick, untreated or treated subjects with the aim of correlating changes in their characteristics to the pathophysiology and pharmacotherapy of diseases. In the process of drug discovery the technique allows in vitro targeting of a distinct receptor thought to be involved in the pathophysiology of a given disease which thus may yield important information regarding selectivity, specifity and/or affinity of novel compounds intended for use as therapeutic drugs (1).

A wide range of assays have been developed. Applications in clinical research often involve the study of variations in the expression of various receptors in dynamic situations where receptor properties may alter along a timescale and profile measurements are necessary, for example in drug-response or circadian studies. In order to measure these alterations effectively, it is necessary to take samples for assay at set intervals over a certain time period, e.g. before and after drug application. In most cases this means that many assays have to be performed within a short time for each patient, thus necessitating rapid sampling and assay techniques which generally involves a variety of experimenters working on the same system. In the drug development process many thousands of compounds have to be screened before one can be introduced as new drug.

Valid results may only be obtained under well defined, standardized experimental conditions which in turn may differ largely depending on various experimental protocols. The scatter of data points is a most critical experimental parameter and validity therefore highly depends on the reproducibility of the results which in turn relies upon the accurancy and precision of the assay steps involved. Ligand binding assays are tedious procedures involving a large number of pipetting steps combined with radioactive exposure of the lab personnel. Manual pipetting techniques have considerable potential for dispensing imprecision and error associated with liquid carry over and contamination. In addition, when several workers are involved in a study, the variation in pipetting skills leads to additional error.

There has been considerable interest in the automation of such procedures but because of the variety of assays, it has not previously been 
possible to develop a flexible and satisfying system. Using a robotic sample processor and a personal computer (PC) we have developed a partially automated radioligand binding assay system which rationalizes and increases assay throughput, improves reliance and reproducibility of results, reduces radioactive exposure and frees lab workers from timeconsuming pipetting jobs.

\section{ASSAY SYSTEM}

We have designed a software (EBSS = equilibrium binding studies software) for IBM compatible PCs controling a Tecan Robotic Sample Processor Model 5032 (dual arm system). The system handles pipetting parameters of two types of experiments, saturation or competition experiments (up to 16 single assays at a time). Up to 24 concentrations of a radioligand or competing compound in a range over 4 orders of magnitude may be defined per experiment. An additive (e.g. antioxidans) may be supplemented to all samples uniformly. Pipetting may be performed alternatively in 1 of 3 different tube or rack types, respectively, with total sample volumes between 200 and $2000 \mathrm{ul}$. Depending on the desired pipetting volumina, the syringes of the sample processor are adapted to achieve maximal pipetting precision ( $\pm 2 \%$ of nominal value). The pipetting sequence can be altered, automatic pipettes may be switched on or off so that certain pipetting steps may be performed by hand or at a later point of time (e.g. tissue pipette, if samples are prepared for an experiment which is to be started later by tissue addition).

All parameter inputs are menu controlled. A hardcopy of the screens with three main input menus defining assay parameters (for the example described later) are shown in FIG. 1 - 3. Depending on substancespecific constants (molecular weights, specific activity) and experimentspecific variables (volumes, concentrations) required reagent-dilutions (radioligand, competing compounds, additive) and titertube arrangements are displayed. The pipetting steps in performance are displayed and may be printed on a hardcopy device together with exact time course informations.

The system provides enough flexibility so that all pipetting parameters can easily be adapted to the large variety of experimental requirements 


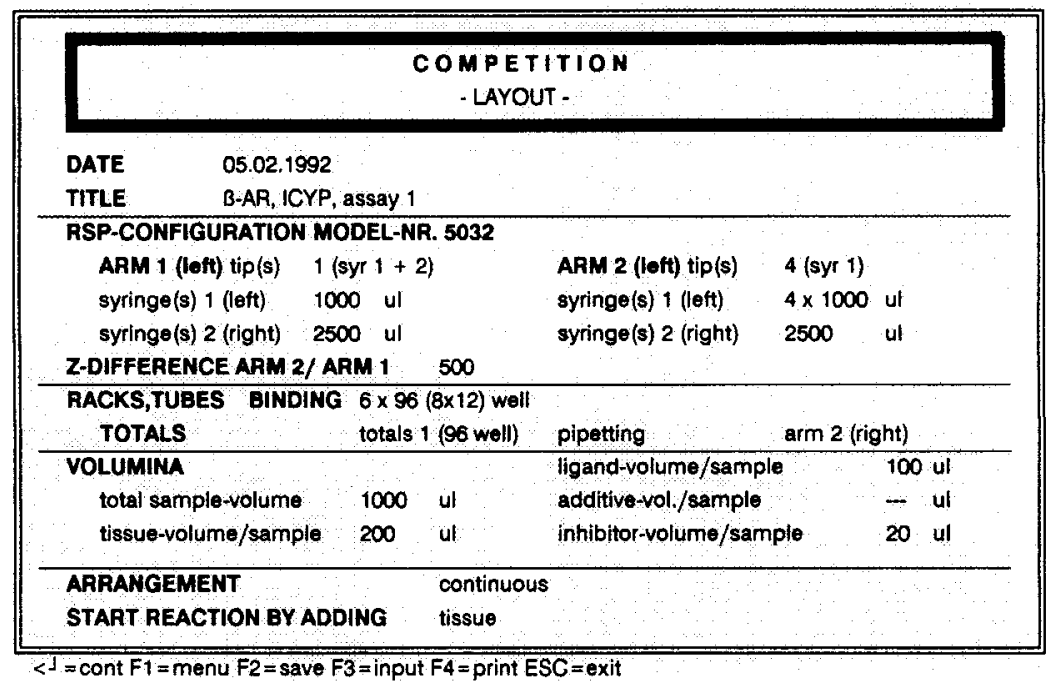

FIG. 1: Screen-hardcopy of input menu defining processor configuration, material and liquid handling parameters.

\begin{tabular}{|c|c|c|c|}
\hline \multicolumn{4}{|c|}{$\begin{array}{c}\text { COMPETITION } \\
\text { SETTINGS }\end{array}$} \\
\hline $\begin{array}{l}\text { ASSIGN METHOD } \\
\text { METHOD-FILE NR } \\
\text { DATE }\end{array}$ & $\begin{array}{l}1 \\
05.021992\end{array}$ & $\begin{array}{l}\text { FILENAME } \\
\text { OPERATOR } \\
\text { TITLE }\end{array}$ & $\begin{array}{l}\text { B-AR, ICYP } \\
\text { B: Liebl } \\
\text { B-AR, ICYP, assay } 1\end{array}$ \\
\hline $\begin{array}{l}\text { LIGAND } \\
\text { molecular weight }\end{array}$ & $\begin{array}{l}1251 \mathrm{CYP} \\
286\end{array}$ & $\begin{array}{l}\text { concentration } \\
\text { pipetting }\end{array}$ & $\begin{array}{l}1.0 \mathrm{E}-10 \mathrm{~mol} / \mathrm{l} \\
\text { automatic }\end{array}$ \\
\hline $\begin{array}{l}\text { ADDITIVE } \\
\text { molecular weight }\end{array}$ & - & $\begin{array}{l}\text { concentration } \\
\text { pipetting }\end{array}$ & $\square$ \\
\hline $\begin{array}{l}\text { LADEL } 1251 \text { CYP } \\
\text { t1/2 } 60 \text { d refdate }\end{array}$ & $\begin{array}{l}\text { charge lot } 192 \\
01.08,1991 \text { age } 80 \text { d }\end{array}$ & $\begin{array}{l}\text { concentration } \\
\text { spocific activity }\end{array}$ & $\begin{array}{l}3.7 \mathrm{E}+13 \mathrm{Bg} / 100 \mathrm{ul} \\
8.4 \mathrm{E}+17 \mathrm{Bg} / \mathrm{mol}\end{array}$ \\
\hline $\begin{array}{l}\text { UNSPECIFIC BINDINC } \\
\text { molecular weight }\end{array}$ & $\begin{array}{l}(-) \text { timolol } \\
433\end{array}$ & $\begin{array}{l}\text { concentration } \\
\text { pipetting }\end{array}$ & $\begin{array}{l}10 \mathrm{E}-06 \mathrm{~mol} / \mathrm{l} \\
\text { automatic }\end{array}$ \\
\hline $\begin{array}{l}\text { TISSUE } \\
\text { automatic stirrer }\end{array}$ & $\begin{array}{l}\text { intact MNL } \\
\text { yes }\end{array}$ & $\begin{array}{l}\text { concentration } \\
\text { pipetting }\end{array}$ & $\begin{array}{l}10 \mathrm{E}+06 \mathrm{colls} / \mathrm{sample} \\
\text { automatic }\end{array}$ \\
\hline
\end{tabular}

FIG. 2: Screen-hardcopy of input menu defining substance- and tissuespecific parameters. 


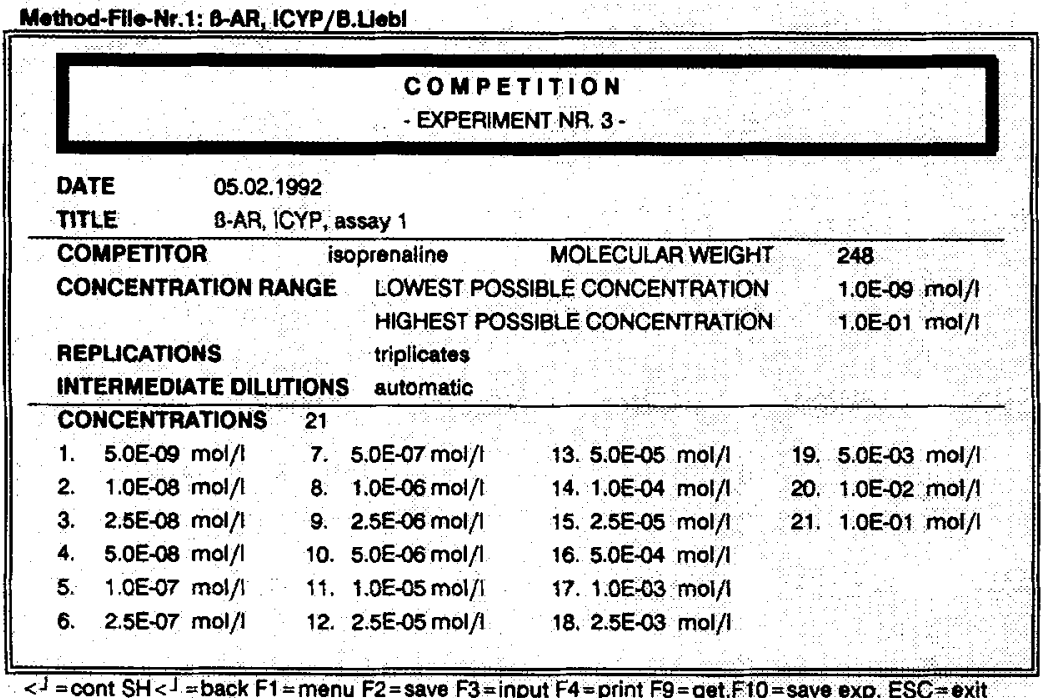

FIG. 3: Screen-hardcopy of input menu describing one competition experiment. Up to 16 different experiments are possible per run.

in binding assays. All parameters can be saved in so-called method files and loaded bypassing the input functions, they may be copied, deleted or revised and saved anew. Other options allow a parameter-listing or the generation of an ASCll-format file which may be later combined with radioactivity measurements for data analysis.

If separation of bound from unbound radioactivity is performed by centrifugation, the system may be additionally used for removal of the supernatant.

\section{APPLICATIONS}

The advantages of the system is demonstrated in the following by a set of competition experiments which were performed in our lab for characterization of binding sites for ${ }^{125}$ iodocyanopindolol ( ${ }^{125} \mathrm{ICYP}$ ) in human peripheral mononuclear leucocytes (MNL) (2-5). 
Using the sample processor three competition experiments (in triplicates) with 8,24 and $95 \mathrm{pmol} / \mathrm{I}^{125} \mathrm{ICYP}$, respectively, and 21 concentrations of isoprenaline in the concentration range of $10^{-10}-10^{-1} \mathrm{~mol} / \mathrm{I}$ were prepared. Total and unspecific binding (in duplicates) were determined in parallel samples with and without $10^{-6} \mathrm{~mol} / \mathrm{l}$ of (-)-timolol. Alltogether 70 specimens per experiment (210 allogether) were prepared with varying volumes of buffer, various isoprenaline dilutions, a constant volume of radioligand- (100 ul) and timolol-solution ( $20 \mathrm{ul}$ ) as well as $200 \mathrm{ul}$ of cellsuspension to achieve a total reaction volume of $1000 \mathrm{ul}$. FIG. 1 - 3 show hardcopies of the input screens for assay-parameter definition for one of these experiments.

Before introduction of the assay system in our lab one person was employed for at least 4 hours for sample preparation for such a set of experiments, while another lab worker was occupied with cell preparation. Using the processor sample preparation could be achieved by a single experimenter parallel to preparation of MNL by density gradient centrifugation. After parameter definition, working time for sample preparation was reduced to arranging the titer tubes $\left(1 \mathrm{ml} \mathrm{Biorad}^{\mathbf{R}}\right.$ in microtiterplate-sized racks) and preparing stock solutions for radioligand and competing compounds (isoprenaline, timolol) according to instructions from the program. Automatic pipetting of one experiment took about 10 minutes.

Experiments were started by adding $200 \mathrm{ul} \mathrm{pMNL}$ suspension in a concentration of $5 \times 10^{6} \mathrm{cells} / \mathrm{ml}$ to each of the 210 specimens. After incubation in a waterbath $\left(2 \mathrm{~h}, 37^{\circ} \mathrm{C}\right)$ the sample-racks were centrifuged at $5000 \mathrm{~g}$ for 10 minutes and transferred back to the lab robot. Bound radioactivity was separated from the unbound ligand by removing the supernatant by the machine. Compared to the conventional rapid filtration-method over glass fiber filters this procedure saved material (no filters necessary), time and radioactive exposure of the experimenters.

The radioactive counts were evaluated using a $\mathrm{PC}$. Due to the pipetting precision of the sample robot scatter of data points was in the range of $\pm 4 \%$ of the mean value. To determine the binding parameters (binding capacity $B \max _{1}$ and $\mathrm{Bmax}_{2}$ for high and low affinity binding sites, the respective equilibrium dissociation constants $\mathrm{Ki}_{1} / \mathrm{Ki}_{2}$ for isoprenaline and $\mathrm{Kd}_{1} / \mathrm{Kd}_{2}$ for $\left.{ }^{125} \mathrm{ICYP}\right)(2)$ data were mathematically fitted to a binding 


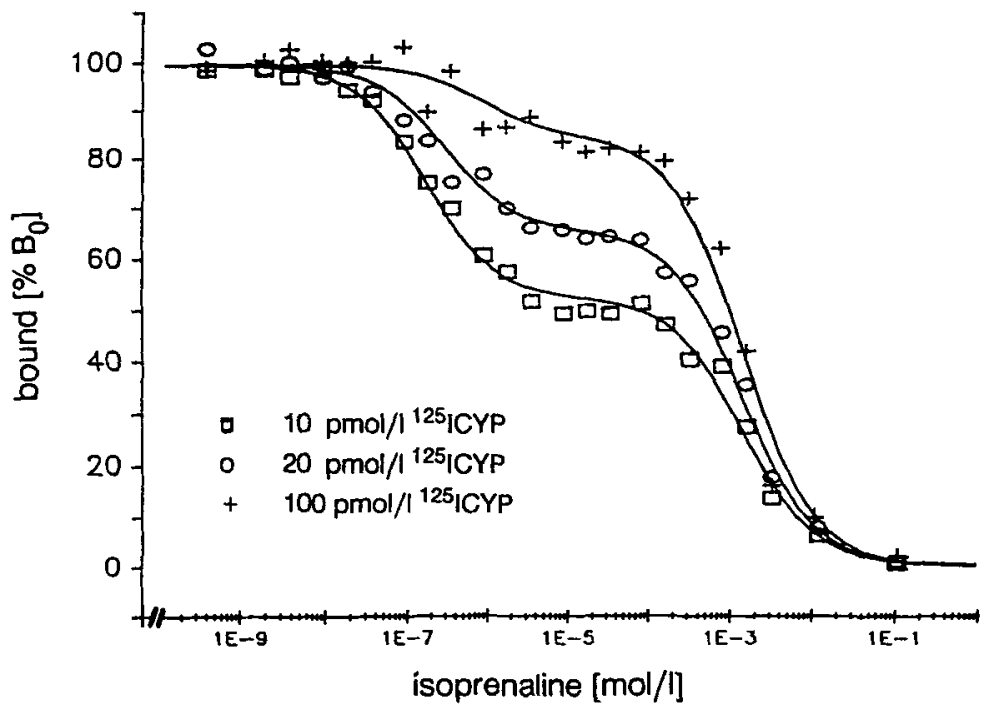

FIG. 4: Competition curves for isoprenaline with $3{ }^{125} \mathrm{CYP}$-concentrations. $\mathrm{B}_{\mathrm{O}}$ : specific binding, Bmax $: 510$ sites/cell, Bmax $: 9180$ sites/cell; $\mathrm{Ki}_{1}: 2.6 \times 10^{-7}, \mathrm{Ki}_{2}: 4.2 \times 10^{-3}$ (isoprenaline), $\mathrm{Kd}_{1}: 1 \times 10^{-11} \mathrm{~mol} / \mathrm{l}, \mathrm{Kd}_{2}$ : $2.9 \times 10^{-9}\left({ }^{125}, \mathrm{CY} \beta\right)$.

equation for two classes of binding sites using a computer-based nonlinear iteration procedure (FIG. 4).

A summarized comparison of time consumption and exposure to radioactivity with and without use of sample processor and $P C$ is given in TABLE 1. Alltogether $70 \%$ of working time was saved ( 84 min compared to $302 \mathrm{~min}$ ). Radioactive exposure was minimized to the time of transferring the sample racks from the robot to the waterbath, to the centrifuge and back to the robot. After preparing the radioligand working solution no further direct contact with radioactivity was necessary.

The assay system has been applied in several clinical studies (e.g. circadian and drug-response studies) on receptor expression under physiologic, pathological and therapeutic conditions. Results from these investigations have been published elsewere (6-11). They implied multiple satu- 
TABLE 1.

Comparison of time consumption and exposure to radioactivity $(-=$ none, $+=$ low, $++++=$ high) with and without use of sample processor and PCs for 3 competion experiments (21 concentrations in triplicates each).

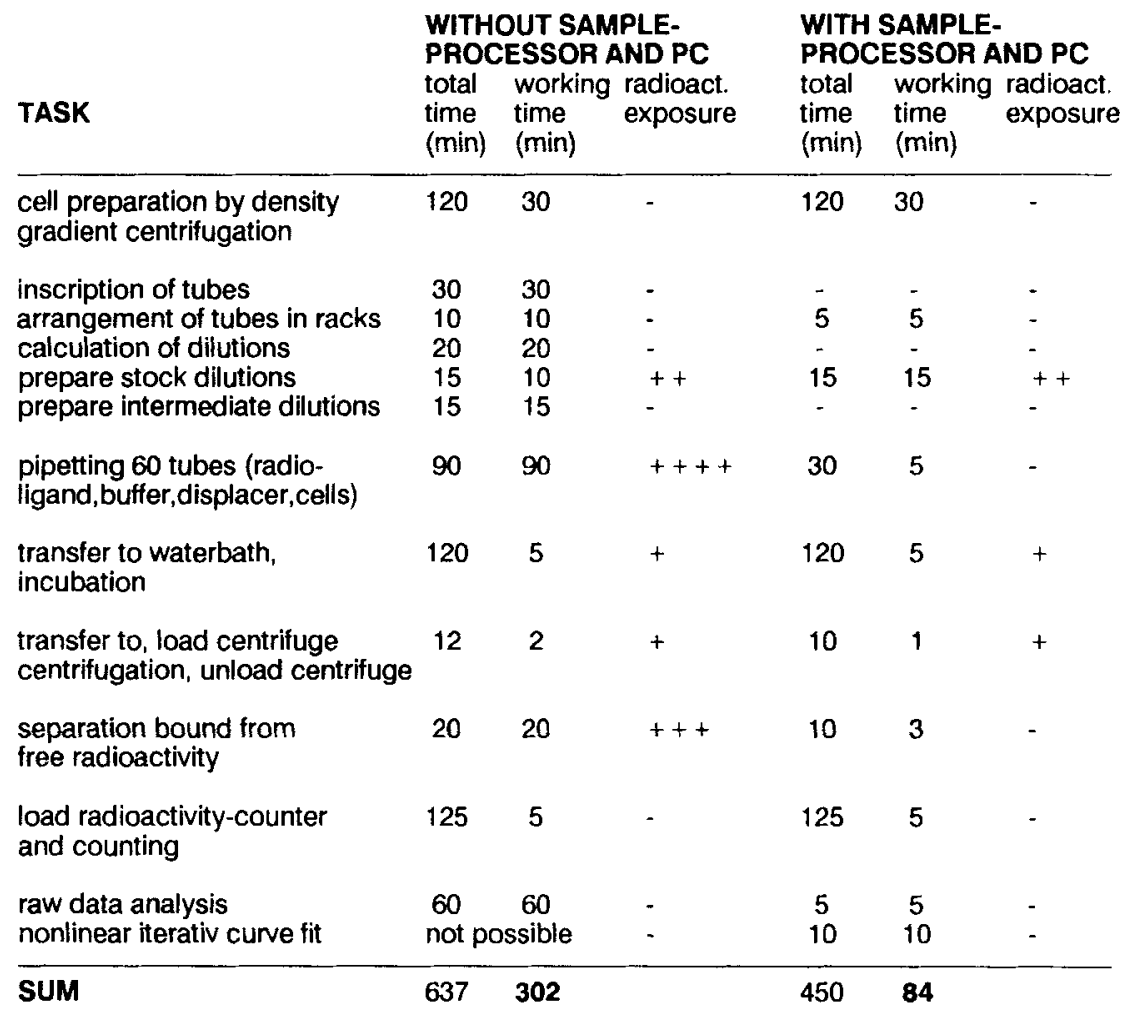

ration experiments, for example at 4 hour intervals and $30,60,120,180$, 240 and 360 minutes after drug application. Up to 14 experiments with 12 radioligand concentrations per experiment had to be performed within 36 hours for each subject $(8,10)$. Without the lab robot 2 persons were busy for 1 day preparing the assays for such a study (inscription of titer tubes, arranging them in racks, making reagent dilutions, pipetting jobs). By employing the lab robot preparation time was reduced to about $4 \mathrm{~h}$ and could be achieved by a singie technician parallel to other tasks in the course of the study. 
The system has also proven effective in the research department of a major German pharmaceutical company. It is applied there for the screening of novel compounds for possible binding interaction using the option of performing multiple competition experiments (up to 16 per run) with a small number of concentrations ( 1 to 4 ) per substance to be investigated. The responsible scientists report that the same number of experiments which previously afforded 3 technicians is performed now by a single person in half of the time.

\section{CONCLUSIONS}

Radioligand binding assays are a well established technique in pharmacological research. They are technically simple to perform, but time-consuming and prone to error if performed manually. Valid information is only obtained if conditions are carefully controlled. Using a robotic sample processor and IBM compatible PCs a flexible, partially automated assay system has been developed which rationalizes and increases assay throughput, improves reliance and reproducibility of results and minimizes radioactive exposure of experimenters.

\section{REFERENCES}

1. Williams, M.; Radioligand binding: issues and experiences in the drug discovery process, part 1. Du Pont Biotech Update 6 (2): 5-11, 1991.

2. Anhäupl, T.; Liebl, B.; Remien, J. Kinetic and equilibrium Studies of $(-)^{125}$ iodocyanopindolol binding to B-adrenoceptors on human lymphocytes: evidence for the existence of two classes of binding sites. J. Recept. Res. 8, 47-57, 1988.

3. Liebl, B.; Anhäupl, T.; Haen, E.; Remien, J. Effect of thiols on $B_{2}$ adrenoceptors in human mononuclear leucocytes. Naunyn Schmiedeberg's Arch Pharmacol. 338, 523-528, 1988.

4. Liebl, B.; Remien, J. Competition of B-adrenoceptor agonists with high and low affinity binding sites for 125 iodocyanopindolol in human mononuclear leucocytes. Naunyn Schmiedeberg's Arch. Pharmacol. 339, Suppl., R 92, Nr. 367, 1989. 
5. Haen, E.; Liebl, B.; Lederer, T.; Pliska, V. Revised radioreceptor assay of $B_{2}$-adrenoceptors expressed on peripheral mononuclear leucocytes (pMNL). J. Receptor Res. 11, 129-140, 1991.

6. Haen, E.; Emsiander, H.P.; Liebl, B.; Langenmayer, I.; Remien, J. Zirkadiane Variationen bei der Expression von $\mathrm{B}_{2}$-Adrenozeptoren an peripheren Lymphozyten von Gesunden und Asthmatikern. Atemwegs- und Lungenkrankheiten 15, 387-388, 1989.

7. Haen, E.; Przybilla, B.; Liebl, B.; Eberlein, B.; Pliska, V.; Ring, J. Influence of UVA-irradiation on the expression and function of $B_{2}$ adrenoceptors on peripheral mononuclear leucocytes (pMNL). Allergol. 12, Suppl., 7, FC 31.04, 1989.

8. Liebl, B.; Haen, E,; Romacker, U.; Nguyen, P.T.; Remien, J. The use of robots and computers in the organisation of studies on the circadian variation of $\mathrm{B}_{2}$-adrenoceptor sites in peripheral mononuclear leucocytes. Chronobiol. internat. 7, 235-238, 1990

9. Langenmayer, I.; Haen, E.; Emslander, H.P.; Hauck, R.; Liebl, B.; Remien, J. Der Einfluß von Theophyllin auf die Expression und Funktion von $\mathrm{B}_{2}$-Adrenozeptoren an peripheren Lymphozyten von Asthmatikern. Atemwegs- und Lungenkrankheiten 16, 278-280, 1990.

10. Haen, E.; Hauck, R.; Emslander, H.P.; Langenmayer, I; Liebl, B; Schopohl, J.; Remien, J.; Fruhmann, G. Expression and function of $\mathrm{B}_{2}$ adrenoceptors, CAMP- and cortisol-plasmaconcentrations in healthy men and untreated asthmatic patients complaining of nocturnal asthma. Chest 100, 1239-1245, 1991.

11. Trunk, E.; Anhäupl, T.; Liebl, B.; Pscheidl, E.; Träger, K.; Georgieff, M.; Rügheimer, E. Rezeptorbindungsstudien als Leitlinie für die Dosierung von Katecholaminen. Anästhesist 40, Suppl., 108, FV 7.4 1991 